Arq. Bras. Med. Vet. Zootec., v.70, n.1, p.53-56, 2018

\title{
Placental osseous metaplasia associated with abortion in a mare: case report
}

\author{
[Metaplasia óssea placentária associada a aborto em uma égua: relato de caso] \\ P.A. Lima, C. Eckstein, R. Ecco, R.L. Santos* \\ Universidade Federal de Minas Gerais - Escola de Veterinária - Belo Horizonte, MG
}

\begin{abstract}
The aim of this report is to describe a case of marked osseous metaplasia in the placenta associated with abortion in a mare. A 19-year-old Campolina mare with a history of multiple parturitions and absence of reproductive failure, aborted a fetus with approximately six months of gestation. There were no gross changes in the fetus and the placenta. Microscopically, there was multifocal replacement of fetal connective mesenchyme of the chorionic villi with well differentiated and partially mineralized osseous tissue (confirmed by von Kossa staining). To further characterize the collagenous component of the lesion, sections of the placenta were stained with Masson's trichrome and Picrosirius red. Osseous tissue deposition had abundance of type I collagen. To the best of our knowledge, this is the first report of osseous metaplasia in the placenta of a mare associated with abortion at mid gestation, presumably due to placentary insufficiency.
\end{abstract}

Keywords: equine, ossification, osseous matrix, collagen, chorionic villi

\section{RESUMO}

O objetivo deste relato é descrever um caso de metaplasia óssea em placenta equina, associada a aborto. Uma égua da raça Campolina, com aproximadamente 19 anos de idade, após múltiplas gestações e sem histórico de alterações reprodutivas, abortou feto com idade aproximada de seis meses. Não foram observadas alterações macroscópicas no feto e na placenta. Microscopicamente, havia substituição do mesênquima de vilosidades coriônicas por tecido ósseo bem diferenciado e parcialmente mineralizado (confirmada pela coloração de von Kossa). Para caracterização do componente colagenoso, foram realizadas colorações de tricrômico de Masson e picrosirius red. O tecido ósseo tinha predominância de colágeno do tipo I. Este é o primeiro relato de metaplasia óssea na placenta equina, associada a aborto no terço médio da gestação, presumivelmente devido à insuficiência placentária.

Palavras-chave: equino, metaplasia, matriz óssea, colágeno, vilosidades coriônicas

\section{INTRODUCTION}

A normal fetal development requires a completely functional placenta, which provides oxygen and nutrients to the fetus and eliminates fetal catabolites (Leiser and Kaufmann, 1994). The equine placenta is classified as microcotyledonar, epitheliochorial, and diffuse. Placentation, i.e. formation of microcotyledons, begins at 60 days of gestation. At 100 days of gestation, the placental structure becomes more complex, forming projections that increase the maternal-fetal contact surface, reaching maximum development at 150 days of gestation with considerable deposition of connective tissue (Samuel et al., 1974).
Proper placental development and function is essential for maternal-fetal interactions and fetal development and health. Moreover, placental physiology is directly related to the surface area and vascularization of the microcotyledons (Allen et al., 2002).

Pathological ossification of soft tissues characterizes osseous metaplasia or heterotopic ossification. This condition occurs due to differentiation of mesenchymal cells into osteoblasts that are capable of synthesizing collagenous osseous matrix, which is latter mineralized, becoming well differentiated bone tissue.

Recebido em 4 de março de 2017

Aceito em 10 de maio de 2017

* Autor para correspondência (corresponding author)

E-mail: rsantos@vet.ufmg.br 
The aim of this report is to describe a case of marked osseous metaplasia in the placenta associated with abortion in a mare.

\section{CASE REPORT}

A 19-year-old Campolina mare with a history of several parturitions and absence of reproductive failure, aborted a fetus with approximately 6 months of gestation. The owner provided an informed consent for use of pathologic data in this report. The mare was from a small farm with seven horses in total. All horses were regularly treated with ivermectin, and annually vaccinated against Equine Herpesvirus, rabies, and tetanus. According to the owner, negative results for glanders and equine infectious anemia were required for introduction of animals in the farm and prior to transportation to local or national fairs. These horses were fed hay supplemented with commercial equine ration.

This was the first abortion recorded in this farm. According to the owner, the mare was subjected to intensive exercise, with approximately $50 \mathrm{Km}$ of walking and trotting.

The aborted fetus and placenta were sent for gross and histopathologic examination at the Veterinary Pathology Laboratory, Veterinary
School, Universidade Federal de Minas Gerais (Belo Horizonte, Brazil). Both fetus and placenta were well preserved and had no gross lesions. Several fragments of the placenta, and fetal liver, kidney, and lungs were fixed in buffered $10 \%$ formalin, processed for paraffin embedding, cut at $5 \mu \mathrm{m}$, and stained with hematoxylin and eosin, Masson's trichrome (staining of collagen), and von Kossa (staining of mineralized tissues) for examination under light microscopy (Luna, 1968), and picrosirius red (differential staining of collagen types) for examination under polarized light (Santos et al., 1997).

Microscopically, there were no lesions in fetal tissues. In the placenta, there was multifocal replacement of fetal connective mesenchyme with well differentiated partially mineralized osseous tissue, with active osteoblasts and osteocytes within lacunae in the osseous matrix. Most of the chorionic villi examined were affected (Figure 1). Partial mineralization of the osseous matrix was further confirmed by von Kossa staining (Figure 1). These morphologic findings are compatible with immature well differentiated osseous tissue, supporting the histopathologic diagnosis of severe multifocal osseous metaplasia.

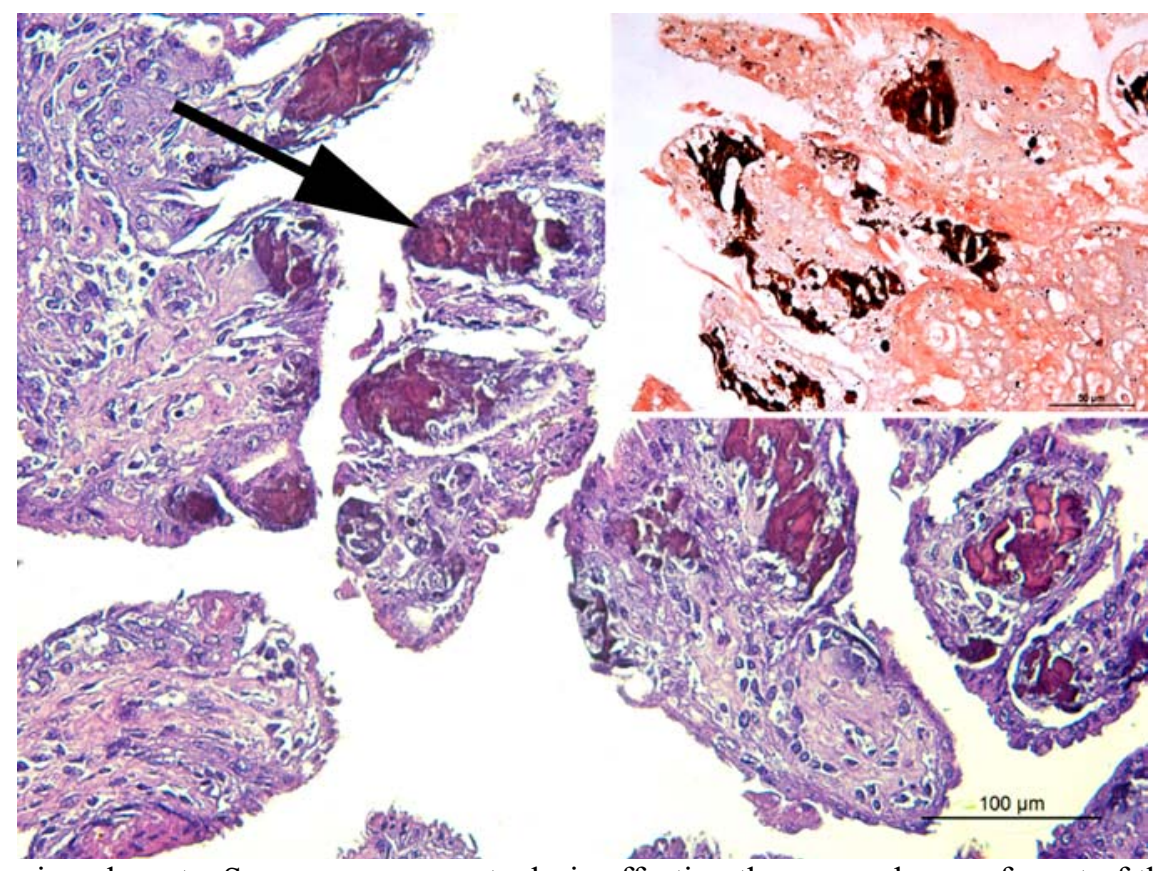

Figure 1. Equine placenta. Severe osseous metaplasia affecting the mesenchyme of most of the chorionic villi, with partially mineralized osseous matrix (arrow). Hematoxylin and eosin; Bar $=100 \mu \mathrm{m}$. Inset: mineralized matrix stained by Von Kossa staining; Bar $=50 \mu \mathrm{m}$. 
To further characterize the collagenous component of the lesion, sections of the placenta were stained with Masson's trichrome and picrosirius red (Figure 2). As expected, the collagen in the mesenchyme stained lightly blue with the Masson's trichrome, whereas areas of ossification had a more intense collagen staining due to the higher density of collagen fibers in those foci (Figure 2). Furthermore, picrosirius red staining under polarized light demonstrated abundance of type I collagen (red birefringence) associated with the foci of osseous metaplasia, with predominance of type III collagen (green birefringence) in areas of unaffected mesenchyme (Figure 2).

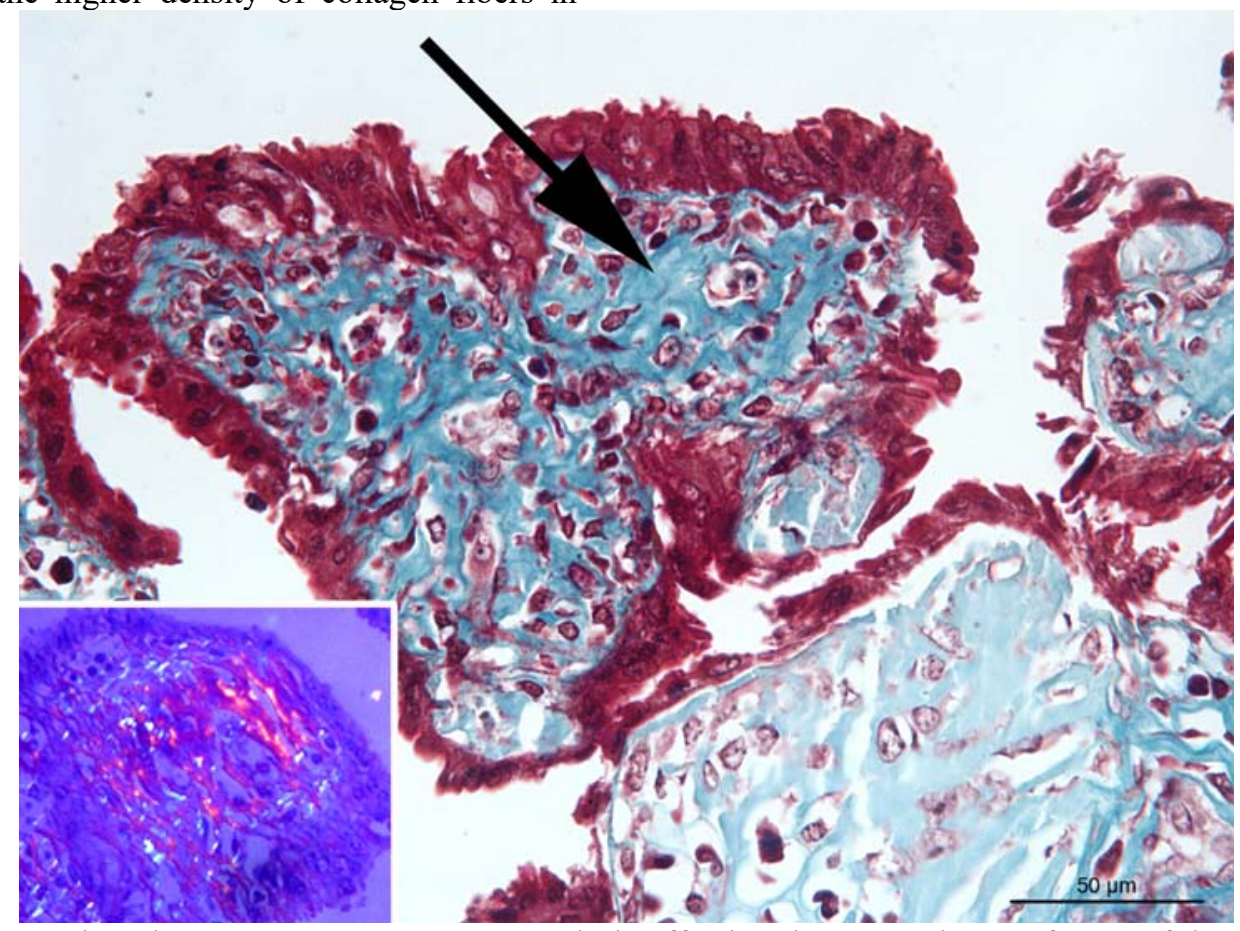

Figure 2. Equine placenta. Severe osseous metaplasia affecting the mesenchyme of most of the chorionic villi. Denser collagen fibers (blue) in foci of osseous metaplasia (arrow); Masson's trichrome staining; Bar $=100 \mu \mathrm{m}$. Inset: predominance of type I collagen fibers (red birefringence) in foci of osseous metaplasia; Picrosirius red.

\section{DISCUSSION}

To the best of our knowledge, this is the first reported case of severe osseous metaplasia in the chorionic villi associated with abortion in a mare with an approximate gestational age of 6 months. Placental osseous metaplasia appears to be a quite uncommon condition, since there is only one previous report in a goat, but in this previously reported case, the condition was diagnosed at the end of gestation after a cesarean delivery, and the lesion was focal and apparently with no clinical consequences (Santos and Nascimento, 1996). Interestingly, it has been demonstrated that equine placental mesenchymal stem cells are capable of osteogenic differentiation (Seo et al., 2013), which can support the hypothesis that mesenchymal stem cells may have been subjected to osteogenic stimuli that lead to ossification of the mesenchyme of chorionic villi in this case. Osseous metaplasia affecting the endometrium is a rare condition that may be associated with subfertility in human patients (Lloyd and Marcus, 2012).

Considering that (i) in the present case no lesions compatible with infectious or non-infectious causes of abortion in horses were observed; (ii) the placenta plays a very critical role for fetal development (Leiser and Kaufmann, 1994); and (iii) the lesion affected most of the chorionic villi in the samples that were examined, it is likely that the lesion may have interfered with the function of the placenta, leading to placental insufficiency and abortion. 
Osseous metaplasia affecting different tissues of horses have been previously reported, although those are rare cases with well defined causes. Donaldson et al. (2012) described a case of osseous metaplasia in the conjunctival mucosa of a horse with chronic and recurrent conjunctivitis. Multiple foci of osseous metaplasia have been described in a case of fibroblastic fibrosarcoma associated with equine influenza vaccination site in a horse (Kannegieter et al., 2010). In contrast, no neoplastic or inflammatory changes were associated with the metaplasia in this case, and therefore it may be considered idiopathic.

In conclusion, this is the first report of osseous metaplasia in the placenta of a mare, with marked involvement of chorionic villi, and association with abortion at mid gestation, presumably due to placentary insufficiency.

\section{ACKNOWLEDGEMENTS}

Work in RLS lab is supported by $\mathrm{CNPq}$ (Conselho Nacional de Desenvolvimento Científico e Tecnológico, Brasil), FAPEMIG (Fundação de Amparo a Pesquisa do Estado de Minas Gerais, Brasil), and CAPES (Coordenação de Aperfeiçoamento de Pessoal de Nível Superior, Brasil). TAP and RLS have fellowships from CNPq (Brasil).

\section{REFERENCES}

ALLEN, W.R.; WILSHER, S.; TURNBULL, C. et al. Influence of maternal size on placental, fetal and postnatal growth in the horse. I. Development in utero. Reproduction, v.123, p.445-453, 2002.

DONALDSON, D.; MATAS, M.; STEWART, J. Osseous metaplasia in the conjunctiva of a horse presenting with recurrent ulcerative keratitis. Equine Vet. Educ., v.24, p.4-7, 2012.
KANNEGIETER, N.J.; SCHAAF, K.L.; LOVELL, D.K. et al. Myofibroblastic fibrosarcoma with multifocal osseous metaplasia at the site of equine influenza vaccination. Aust. Vet. J., v.88, p.132-136, 2010.

LEISER, R.; KAUFMANN, P. Placental structure: in a comparative aspect. Exp. Clin. Endocrinol. Diabetes, v.102, p.122-134, 1994.

LLOYD, J.; MARCUS, S. Severe endometrial ossification with subsequent conception and placenta accreta: a case report. Am. J. Obstet. Gynecol., v.207, p.e7-e8, 2012.

LUNA, L.G. Manual of histologic staining methods of the Armed Forces Institute of Pathology. 3.ed. New York: McGraw Hill, 1968. [258p.].

SAMUEL, C.A.; ALLEN, W.R.; STEVEN, D.H. Studies on the equine placenta. J. Reprod. Fertil., v.41, p.441-445, 1974.

SANTOS, R.L.; CASSALI, G.D.; MARQUES JR., A.P. et al. Análisis de colágeno por el método polarización-picrosirius en placetomas de vacas lecheras con expulsión normal y retención de placenta. Arch. Reprod. Anim., v.1, p.22-27, 1997.

SANTOS, R.L.; NASCIMENTO, E.F. Metaplasia óssea na placenta caprina. Arq. Bras. Med. Vet. Zootec., v.48, p.619-621, 1996.

SEO, M.S.; PARK, S.B.; KIM, H.S. et al. Isolation and characterization of equine amniotic membrane-derived mesenchymal stem cells. $J$. Vet. Sci., v.14, p.151-159, 2013. 